\title{
A Museum Cruise in Foul Waters: An Empirical Analysis of the Debate Triggered by the Proposal to Move the Norwegian Viking Ships from Bygdøy to Bjørvika*
}

\author{
Joar Skrede
}

\begin{abstract}
This article analyzes the debate that ensued from a suggestion to relocate three Norwegian Viking ships from Bygdøy to Bjørvika. People do not only debate the ships' material vulnerability but they also express different views of what a modern museum is and should be. Some want to upgrade and preserve the existing museum, while others want to relocate the ships and integrate them in a wider culture-led urban regeneration agenda. The ships are torn between local, regional, and national political interests, and people have different opinions about the histories in which they should be inscribed. The empirical corpus is primarily made up of newspaper articles from the last 20 years, and the different arguments are systemized and presented thematically. In the closing remark, the article suggests that the Viking Ship Museum would benefit from a more clearly defined long-term agenda.
\end{abstract}

[Keywords: Museums; material culture; urban development; museum debate; heritage objects; The Viking Ship Museum; The Oseberg ship; Bygdøy, Bjørvika, Oslo, Norway. Keywords in italics are derived from the American Folklore Society Ethnographic Thesaurus, a standard nomenclature for the ethnographic disciplines.]

\section{Introduction}

This article provides a glimpse into a Norwegian heritage debate. The issue of material objects and the different narratives in which they are-and could be-inscribed constitute a fulcrum in the debate. The question is whether three Norwegian Viking ships and a collection of fragile archeological finds from the Viking Age will suffer damage if they are relocated to a new museum. Kirshenblatt-Gimblett has argued that heritage objects are "made, not found" (Kirshenblatt-Gimblett 1998:3). Her point is that there is no heritage object prior to its identification, evaluation, conservation, celebration, and so forth (Kirshenblatt-Gimblett 1998:149). However, the wooden fragile objects were found; they were excavated from Norwegian burial mounds. The objects existed prior to any human recognition of them, and their physical condition is now a main issue in the public debate. Thus, the following case study may be read as an example of the dialectical relation between heritage as a discursive collective process and the materiality of the objects. Objects influence the way people talk about them, and the way people talk about objects may trigger actions that influence the objects' physical condition. Heritage practices may therefore be seen as performative, as they carry a potential to

\footnotetext{
*This peer-reviewed contribution was accepted for publication in Museum Anthropology Review on November 12, 2015. The work is licensed under the Creative Commons Attribution 4.0 International License. To view a copy of this license, visit http://creativecommons.org/ licenses/by/4.0/
} 
bring into being what they enact (Hafstein 2012:508).

Several attempts have been made to account for the "rising tide of heritage" (Hafstein 2009:11). Some of the points suggested are a renewed interest in, for example, history, heritage's association with the tourist industry, local patriotism, globalization, urban development, and commodification of culture (Hafstein 2009:11-12) -all of which are constituents in the Norwegian debate. Heritage creates a discursive space in which different issues can be discussed and disputed (Hafstein 2009:13). However, not only heritage scholars debate the relocation issue; politicians and laypersons also participate. Heritage may therefore be viewed as a "metacultural" process, in that it extends "museological values and methods (collection, documentation, preservation, presentation, evaluation, and interpretation)" (KirshenblattGimblett 2006:161). The following case study may be read as an example of heritage as a public performance where actors try to re-order the relation between people and objects. Heritage, then, is not only a description, but an intervention into the social and physical sphere as well (Hafstein 2012:508).

\section{Case Presentation}

Some people with an interest in cultural heritage may know about the Norwegian Viking ships, in particular the Oseberg ship (Figure 1). It was pulled ashore and used as a burial ship for two women in the year 834. The ship also contained a number of burial gifts, including several sledges, five carved animal heads, five beds, fifteen horses, six dogs, and two small cows (Museum of Cultural History, 2012). In 1904, the ship was excavated from the Oseberg farm in Vestfold County in eastern Norway. Since 1957, the Oseberg finds have been exhibited in the Viking Ship Museum - a separate unit in the Museum of Cultural History. The museum is located at the Bygdøy peninsula a few kilometers southwest of the city center of Oslo, the capital of Norway.

The debate was triggered by the suggestion to relocate the Viking ships to a new planned Museum of Cultural History in Bjørvika - a harbor that is currently being transformed into an urban waterfront project. A new Opera House and a sequence of high-rise office blocks named Barcode are already completed (Figure 2). The goal is to create a vibrant urban community with over a million square meters of buildings for residential, commercial, and cultural purposes. The decision to relocate the Viking ships to Bjørvika, which was made a couple of decades ago, has led to a long-lasting public debate, demonstrating that museums represent an important element of democratic concern.

People have been questioning whether the ships and other objects will withstand the consequences of removal, but not only the question of the ships' material vulnerability has been debated. People have also expressed different views of what a modern museum is or should be. Different curatorial and educational approaches have been debated, as well as relocation scenarios and museum constellations, and-more fundamentally-different views have been expressed as to in what histories the ships ought to be inscribed. While dealing with local, 


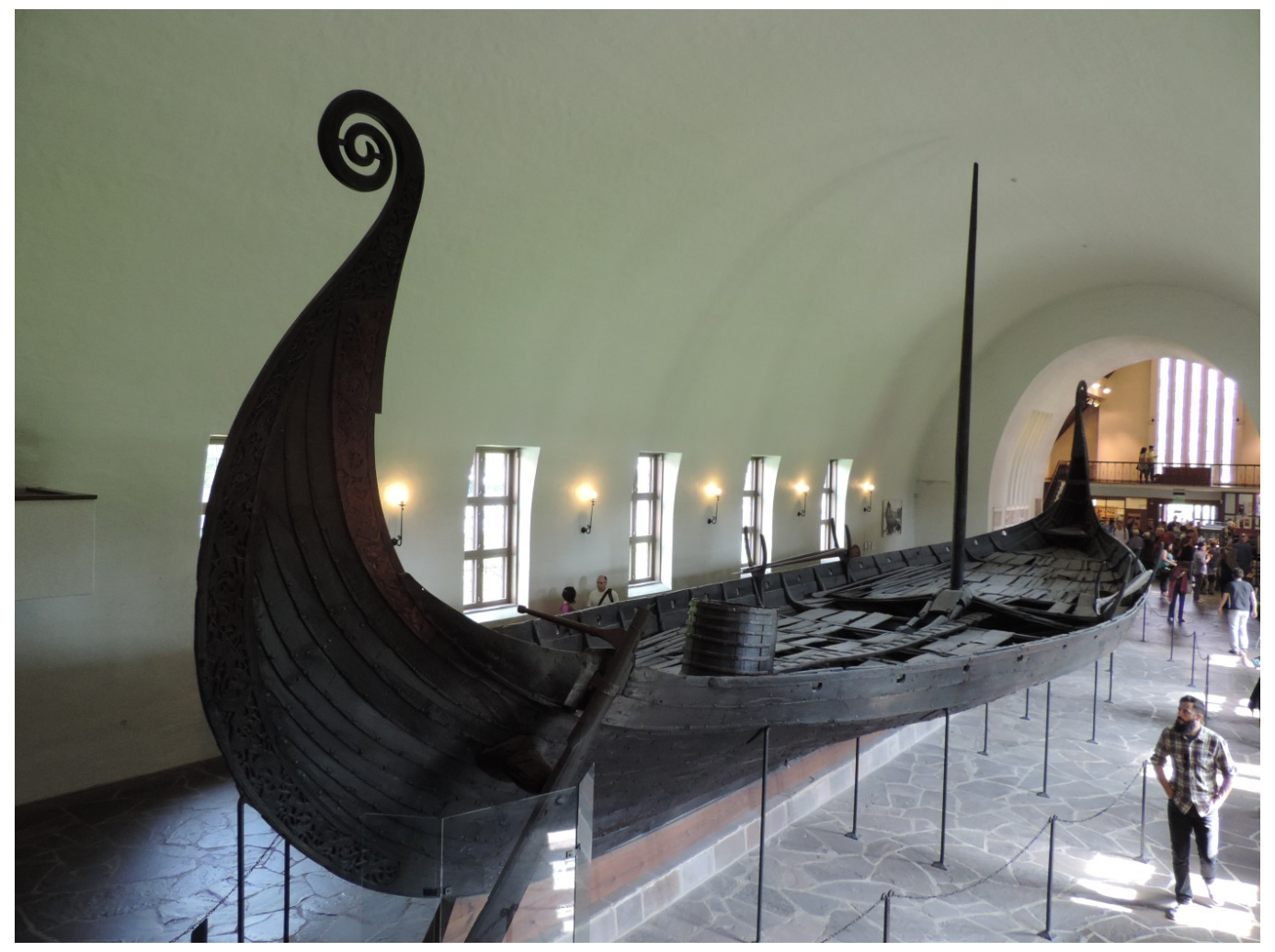

Figure 1. The Oseberg Viking ship exhibited at The Viking Ship Museum at Bygdøy, Oslo, Norway. Licensed under CC BY-SA 3.0 Wikimedia Commons.

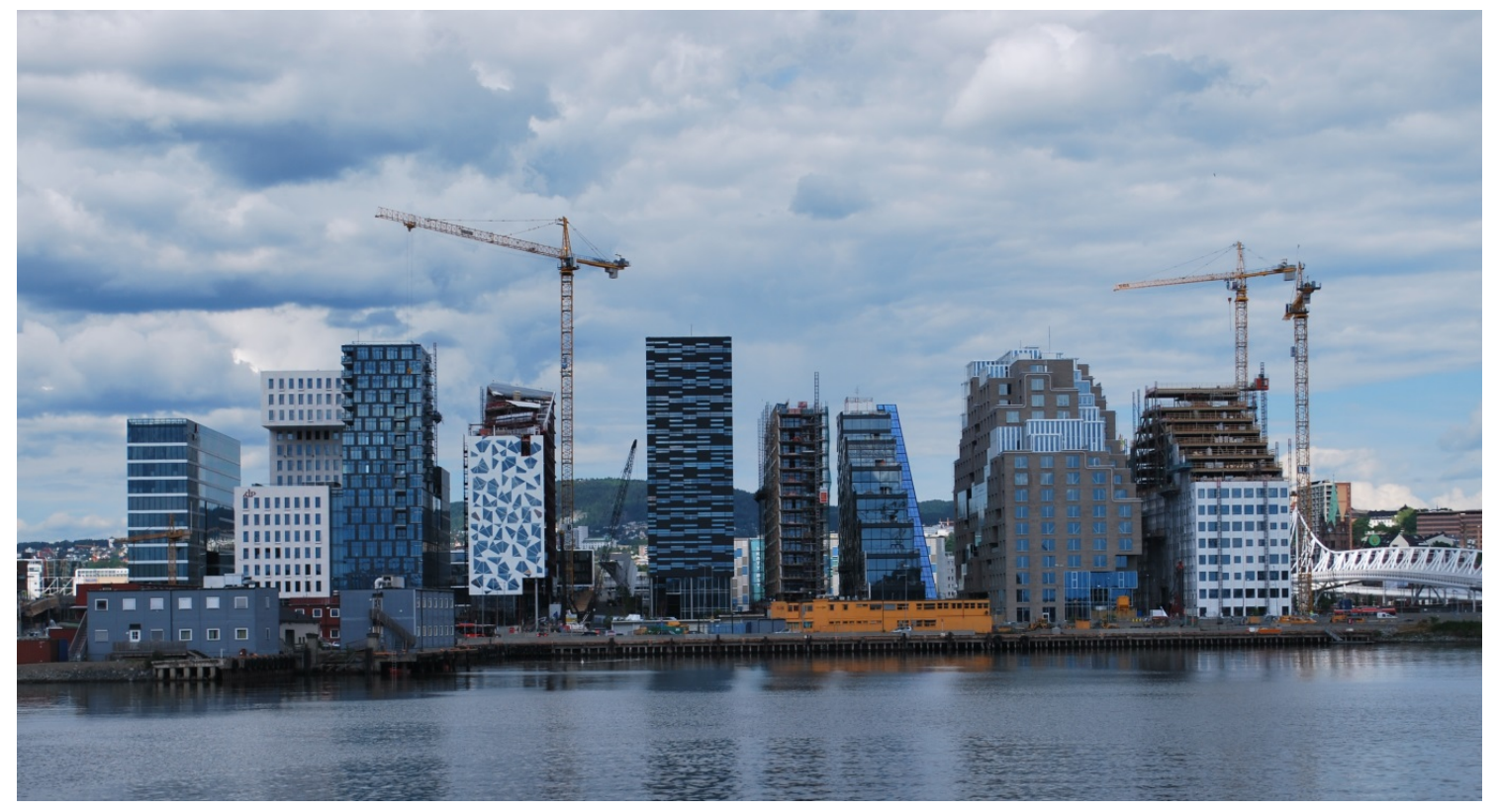

Figure 2. The "Barcode" sequence of high-rise buildings in Bjørvika, Oslo, Norway. Licensed under CC BY-SA 3.0 Wikimedia Commons. 
regional, and national politics, the debate has uncovered diverse views of authenticity. The aim of this empirical analysis is to map people's attitude to the management of the Viking ships, regardless of their specific interest in cultural heritage issues.

The corpus is mainly obtained through the Nordic media database, Retriever. The major part is made up of newspapers (paper and internet). The search was based on a selection of key words (for example, Viking ships and Bygdøy). Actually, several thousand newspaper pages referring to the Viking ships and Bygdøy have been published during the past 20 years, most of which have addressed the proposition to relocate the Viking ships to Bjørvika. Issues dealing with the Museum of Cultural History - with no reference to the Viking ships - have been omitted from the corpus. The objective has been to identify the main arguments for or against relocation. The public debate has been the chief concern. The study may be read as a micro-historical account of the debate. A large empirical corpus is systematized. It may be used for further research, or as an essential document for anyone who wants to learn more about this long and heated debate. For this purpose, the empirical-analytical representation of the relocation quarrel is emphasized.

\section{The Ships' Material Vulnerability}

What has caused most disputes in the museum debate is the question of the ships' material vulnerability. Although Oslo already has a record of controversy about the location of museums and other buildings of culture (see for example Skrede 2014), the debate about the Viking ships is unique in terms of the potential material consequences if something goes wrong. In the early stages of the debate, Aftenposten claimed that wooden material older than 1,000 years is not fit to be moved elsewhere (Editorial 1995:8), which, however, did not avert years of newspaper coverage of the ships' destiny. While firms of consultant engineers submitted many reports on this issue, conclusions have diverged a lot. Reports have been interpreted differently to suit different arguments.

Former manager of the Museum of Cultural History, Egil Mikkelsen, was previously strongly opposed to relocation. In a newspaper interview in 1995, he stated that "moving the ships and the Oseberg finds might end in a scandal because of the fragile shape of the objects" (Sandvig 1995:10). He argued that, unlike many other people, he viewed the matter realistically rather than emotionally. Former City Antiquarian, Hans Jacob Hansteen, similarly voiced a rational approach, claiming that he would be worried by the slightest risk of transportation damage (Klem 1995c:18). Long-standing ship archaeologist at the Viking Ship Museum, Arne Emil Christensen, was worried that certain treasures might be converted into "brown powder" if they were relocated (Løken 1995:2). As for the Shetelig's sledge from the Oseberg finds, which is made up of 1,078 glued fragments and stored in an air-conditioned cabinet, Christensen argued that the public cannot afford the risk that vibrations might pulverize the entire sledge (Klem 1995b:15). The so-called Velure committee, appointed by former Minister of Culture, Åse Kleveland, also opposed relocation. According to the committee, the technical challenges would involve so many elements of uncertainty that they did not approve of the plans (Klem 1996:3). Yngve Kvistad even drew a parallel with the debate in the Ukrainian Department of Science prior to the building of the Tsjernobyl nuclear power plant (Kvistad 2010:2). They also disagreed about the level of danger, what could possibly happen, and what could be done to repair minor 
damages to the ships. Arne Emil Christensen argued, "as long as something can possibly go wrong, we cannot run the risk of relocation" (Kolsrud 2001:18). Engineer Jørgen Andersen explained the principle of risk assessment as "the risk of accident multiplied by the consequences of accident" (Andersen 2010:4). He added that, as for the Viking ships, their value is "immeasurable" and therefore relocation could not be approved (Andersen 2010:4).

While material-based opposition to relocation has been strong, there are also people who support it. Egil Mikkelsen, who previously criticized the plans, later viewed them in a positive light, arguing that the counter-arguments had not convinced him, and that one has to distinguish between total destruction and minor damage - reparable damage ought to be tolerated (Dagsland 2002:40). He accounted for his change of mind by referring to the thorough examination of the storage and security of the ships - as well as to various problems encountered by visitors at the Viking Ship Museum - which become arguments in favor of relocation (Toft 2006). On October 16, 2006, the Museum of Cultural History Board voted for relocation of the Viking ships on certain conditions. After receiving a risk assessment review from Det Norske Veritas and Scandpower Risk Management, former Rector at the University of Oslo, Geir Ellingsrud, referred to the conclusion that it is possible to relocate the Viking ships without causing too much damage. He confirmed that all analyses had been thoroughly examined by the museum Board, which had subsequently recommended relocation of ships and other burial finds (Ellingsrud 2006:12). A corresponding report from the consultant company, Safetec, also argued, "if a specially designed transportation frame construction is built, the ships can probably be relocated with minor risk of serious damage" (Røsholm 2002:44). While considering the rebuilding of today's museum at Bygdøy to be a greater risk, Ellingsrud assured that the ships were bound for Bjørvika (Kristensen 2006:46). Svein Gullbekk rejected Arne Emil Christensen's arguments, claiming that he was exaggerating the risk of damage (Gullbekk 2010:5). A recent report from an international expert committee, however, concluded that relocation would incur a considerable risk. A new building connected to the Viking Ship Museum is the recommended idea (International Expert Committee 2012). Expert committee head, David Saunders, does not believe that irreparable damage will be caused by relocation; yet, he recommends complete 3D recording of the objects - in order that they might be recovered in case of damage. Former director of the Museum of Cultural History, Rane Willerslev, announced that the museum supports the idea of a new Viking Ship Museum at Bygdøy (Hagen 2012:84). Former Minister of Knowledge, Kristin Halvorsen, confirmed that the report would bring the debate about relocation to a close (Christiansen 2012:12). However, the relocation conflict is not settled yet; today Statsbygg [the Norwegian government's key adviser in construction and property affairs] is making plans for a new Viking Period Museum in connection with the existing buildings at Bygdøy. Therefore, some sort of relocation may still be conceived - be it merely local — and the question whether objects will be exposed to damage during the building process has to be considered.

On the basis of this review of the debate so far-which has largely focused on the ships' stability - at least two substantial dividing lines may be identified: the first deals with the acceptance or non-acceptance of risk. The opponents do not accept relocation as long as there is a risk, while the supporters of relocation argue that a small risk is worth taking - that is, as long as it is small. The other dividing line deals with what one wants to achieve besides providing security for the ships as material artifacts. Egil Mikkelsen, one of the most outspoken supporters 
of relocation, argued that the report had not paid appropriate attention to the proximity to Oslo Central Station, which is Norway's most important traffic hub, and that the decision of former Minister of Knowledge, Halvorsen, was a rather rash conclusion (Lillebø 2012:21). This example illustrates that potential rewards besides the conservation of the ships are included in the prolocation arguments. It is important to bear in mind, however, that the report referred to by Mikkelsen, made to order by the Ministry of Education and Research, was titled "Risk Assessment of Moving of Historical Viking Ships from Bygdøy" (International Expert Committee 2012). As the title suggests, the commission of the expert committee does not include the kind of assessment for which Mikkelsen called. In what follows, however, I will comment on some matters of this kind, including the ships' material surroundings - the museum buildingand questions of dissemination.

\section{Tourism and Urban Development}

After meeting an enthusiastic French tourist at the Viking Ship Museum-who was wondering why Oslo had hidden the Viking ships in such a distant area-Svein Erik Haugen proclaimed: "move the Viking ships to Sørenga," a neighborhood in Bjørvika (Haugen 1999:43). A corresponding view was advocated by cultural journalist, Gudleiv Forr, in Dagbladet, who stated that Oslo may develop an international-standard museum arena provided that politicians have visions and capital. In support of Bjørvika, Forr argued that the Viking ships would become a tourist attraction on a level with Guggenheim in Bilbao (Forr 2000:2). Similarly, Egil Mikkelsen drew attention to tourism, pointing out the walking distance from the cruise ships to Bjørvika. He also emphasized the fact that the head office of DnB NOR (Norway's largest financial service group) will be situated in Bjørvika, arguing that the bank might be more likely to sponsor institutions close it its headquarters (Christiansen 2009:8). Mikkelsen also believed that the museum café in Bjørvika would draw more guests than a museum at Bygdøy, arguing that no one travels to Bygdøy to visit a restaurant (Christiansen 2009:8). He claimed that the Viking ships would become "essential elements in the future development of Bjørvika - together with the new Opera House" (Mikkelsen 2001:8). John Tore Norenberg, conservative head of the city development committee, argued that coaches have a rather tight schedule: "coaches cannot afford half hour traffic locks either way to the museum and back; instead they will rather choose alternative destinations!" (Norenberg 2009:27). Gudleiv Forr stated that in Bjørvika the tourists have time to spare for the Viking ships before re-embarking and sailing on (Forr 2010a:62). After the decision not to move the Viking ships, Dagbladet stated that a new museum that does not include the ships cannot, unfortunately, become "the tourist magnet it was intended to be" (Editorial 2012:2) and downplayed the material risk element. In these examples, relocation of the ships is motivated by potential synergies - in this case, tourism and a greater number of visitors.

The Viking ships today rank second—next to Holmenkollen (a ski jump)—as the tourist attraction drawing most visitors in Oslo; still, further growth is a high priority. In the early stages of the debate, "The Progress Party" (Fremskrittspartiet) announced that moving the Viking ships to Bjørvika would make for "the most exciting urban development project in this century" (Christiansen 1997:32). Per Rekdal, senior adviser at the Museum of Cultural History, argued that the Viking ships in Bjørvika would generate "spin-off businesses in more lively surroundings" (Rekdal 2009:17). Obviously, this view was inspired by Richard Florida's (2002) 
ideas, which have been a source of inspiration to city council heads all over the world. The arguments draw on neoliberal ideology, focusing on competition between cities (Peck 2004:740741). To Dagsavisen, Mikkelsen reported that he had not given up the campaign in favor of Bjørvika: "I have read the book about how the Opera came to Bjørvika" (Lilleås 2012). Arne Emil Christensen, though delighted by the tourists' interest in the Vikings, still expressed concerned about potentially "uncritical and vulgar effects of tourism" (Grande 1997:10). There were, however, other ideas of boosting Bygdøy's qualities for tourists. Going by ferry from Midelalderbyen (the Medieval City) to Bygdøy, tourists would experience Oslo from the sea (Borgen 2009:41) and get "a wonderful sightseeing on the fjord into the bargain" (Nissen-Lie 2009:19). Besides, Bygdøy would provide unique maritime surroundings for visitors. In these arguments, the travel to the museum is an attraction in its own right.

\section{The Maritime Surroundings of Bygdøy}

Along with the idea of travelling by boat to Bygdøy, many debaters emphasized the maritime surroundings on the peninsula as an argument for why the Viking ships should remain where they are today. In an editorial, Aftenposten warned us against moving the ships because it would imply "tearing up their roots in a traditional maritime environment-where they contribute to mapping the long lines in the life of a nation of seafarers" (Editorial, 1997). The Maritime Museum, the Viking ships, the Fram Museum, and the Kon-Tiki Museum represent the world's largest collection of maritime museums in the same area (Kolsrud 2001:18). "Why should we not preserve the unity of our four maritime museums at Bygdøy?" Jan G. Langfeldt asked (Langfeldt 2010:3). Maja Bauge, Director of the Kon-Tiki museum, was distressed by the situation, arguing that the Viking ships do not belong in Bjørvika: "Norway is one of the most important seafaring nations in the world; and the four maritime museums at Bygdøy are telling the story of Norwegian navigation up to the present time" (Bauge 2010:5). Jon Winge, writer and engineer, made the point that "Bygdøy is to Norway what Greenwich is to London: The lovely surroundings of Bygdøy accommodate the country's most important maritime museum"-a museum cluster that draws crowds of visitors (Winge 2010:26). He called for improvements of infrastructure and facilities in order to further revitalize the unique museum environment at Bygdøy:

key words are more efficient cooperation between the museums, sea travel (even the trip from Rådhuset [the city hall] to Bygdøy is an experience to asphalt people), as well as improved communication between the two centres (the museums at Bygdøy and the Viking ships/Folkemuseet" [Folkemuseet is an openair museum located next to the Viking Ship Museum]). [Winge 2010:26]

According to Winge, "foreigners can hardly believe their own eyes when seeing the huge amount of historically convincing museum material in the same place" (Winge 2010:26). In an early warning against moving to Bjørvika, tourism director Tor Sannerud described the story of Norwegians' relationship to the sea and seafaring as the governing idea in the museum environment at Bygdøy; he further argued that relocation would inevitably cause a decline in the number of visitors to the remaining museums (Klem 1995a:17). Norwegians are known for their relationship to the sea (in past and present), which is used in the marketing of Bygdøy (Klem 
1996:3). Thor Heyerdahl, son of the famous adventurer, warned that if the Viking ships are moved to a new museum of cultural history in Bjørvika, relocation of the Kon-Tiki museum to Heyerdahl's home town, Larvik, might have to be considered (Andreassen 2010:6). This argument is based on the premise that moving the Viking ships will disrupt the internationally unique museum environment at Bygdøy (Andreassen 2010:6). Undoubtedly, there is a tourism argument in favor of Bygdøy, which, however, attracts less attention than the tourism argument in favor of Bjørvika.

\section{Burial or Sea?}

A basic argument against relocation has been the view that ships and building constitute an inseparable unity. Engineer Knut Røsholm is convinced that all those who care about Norwegian maritime history agree that the ships should remain in "Arnstein Arneberg's [architect] beautiful building, which is a museum cathedral admired by people all over the world" (Røsholm 2002:44). Elisabeth Seip, secretary general of the Society for the Preservation of Ancient Norwegian Monuments argued that the Viking Ship Museum represents an exceptionally successful marriage between building and objects, and that it ought to be preserved in its present form (Seip 2009:16). Historian and cultural mediator Kjell Brynildsen argued that the relocation plans were jeopardizing some of the nation's most valuable treasures. He emphasized the symbiotic relationship between building, interior, and objects created by one of our most prominent architects (Brynildsen 2006:11). The protection campaign of former Director for Cultural Heritage, Nils Marstein, was based on a similar judgment. He emphasized the basically sacral elements that enhance the value of the ships: "the interpretation of the building as a tomb underscores the burial element" (Directorate for Cultural Heritage 2006). He further argued that the "Viking Ship Museum...is one of the few museums that highlight[s] the formal relationship between architecture and exhibited objects" (Directorate for Cultural Heritage 2006). Ellen Semb agreed that the building and the ships evoke a sacral atmosphere in the tomblike monument to the heyday of Norwegian history. She regretted, however, that "the Viking age is limited to burial customs without encompassing broader perspectives" (Semb 2010:16). Correspondingly, Ulf Grønvold argued that although the ships were excavated from burial mounds, the Viking Ship Museum should not be a museum of Norse burial customs. Today, the ships primarily tell us the story of discoveries and daring voyages over vast stretches of open sea (Grønvold 2010:3). He concluded by calling the sites of excavation a straitjacket and "a metaphor that commands all our imagination" (Grønvold 2010:3). Dagfinn Skre, professor of archaeology, questioned whether the ships are "forever to be embedded in a story that is irrelevant to modern people" (Skre 2006:11). Former Director of the Museum of Cultural History, Rane Willerslev, however, while acknowledging the validity of the argument against displaying pagan ships in a sacral building, regarded it as a brilliant idea (Kraft 2012:31). In this context, the discussion whether the ships are to be inscribed in a burial or sea narrative is more important than the discussion of their vulnerability. Those who advocate the present solution, firmly believe that their arguments are so good that the risk of moving hardly need to be considered.

While many people want to preserve the Viking Ship Museum as Gesamtkunstwerk, others find the Bjørvika surroundings more suitable because of their proximity to water. Egil Mikkelsen suggested the idea of moving the Viking ships to the reconstructed waterfront of medieval 
Bjørvika (Mikkelsen 2001:8). Similarly, the support of relocation expressed by Norse philologist Magnus Rindal - early in the process - was partly based on the prospect of moving the ships towards the sea; the study of the zoning plan for Bjørvika, however, caused him to change his mind. He argued that the ships would be caught behind a wall of houses, which is unacceptable (Rindal 2006:12). He claimed that the view towards Hovedøya (the Main Island) and Akershus slott (Akershus Fortress) is gone, and that we cannot allow the ships to hide behind blocks of houses on the shores of an artificial lake (Rindal 2003:44). Maja Bauge argued that moving "the Viking ships behind the Barcode row, where they are caught up in the busy traffic of railway and cars," means moving the Vikings to surroundings in which they do not belong (Bauge 2010:5). Rane Willerslev believed that the dream of a museum in Bjørvika could hardly come true after all, because a planned rail project in the area seemed to encroach on more land than anticipated (Slettholm 2012:12). Culture committee Head, Britt Hildeng (Labour Party), however, was thrilled by the idea of a museum area displaying the history of Norwegian seafaring. Astonishingly, the area she had in mind was not Bygdøy, but instead Sørenga (the aforementioned neighborhood in Bjørvika). The increasing number of finds made in these surroundings suggests that the area is the right one for the Viking ships because it initiates the history of Oslo, she reported to Aftenposten (Herbjørnsrud 1997:28). Later, former City Council Head, Erling Lae argued in favor of moving the Viking ships to their appropriate environment, to "a new mediaeval museum by the sea-alongside the Opera in Bjørvika" (Brække 2007:34). However, many debaters criticized these arguments, one critic stating that the Viking ships belong in Vestfold County (a few hours' drive south of Oslo) because they were discovered there (Wigestrand 1997:2). A number of county and municipal majors in Vestfold also argued in favor of moving the Vikings ships back to the discovery places within their own county (Vasvik et al. 2006:11). It is also interesting to note that Lae changed his mind after he was appointed County Governor of Vestfold. A few years ago, he reported to Uniforum: "if foolish Oslo politicians insist on relocating the ships to Bjørvika, they may just as well be moved to the places of their origin in Vestfold" (Toft 2010).

\section{The History of the Nation or the History of Oslo}

Many people have countered the view that the Viking ships naturally belong to the maritime environment of Bjørvika, by referring not only to the sea or places of discovery, but also to the story to be told. Olav Aaraas, Director of Norsk Folkemuseum, who has taken an active part in this discussion, warns us against paying too much attention to matters of local interest, arguing that the ships represent values of national (even international) importance. His view is supported by two arguments. The first is the claim that a new museum of cultural history - no matter whether the Viking ships are included in it or not-would inevitably become an illogical museum construction because the exhibited objects are of pre-Reformation origin. He called for a union, or cooperation, with the Norsk Folkemuseum, which mainly covers the postReformation era (Aaraas 2004:52). Secondly, he referred to the city museum of Oslo-Oslo Museum - as the appropriate museum for disseminating the history of Oslo. He advocated the relocation of this museum to Bjørvika, where it would tell the story of Oslo from the Middle Ages to the present day-spanning the time from St. Clemen's Church to Barcode (Aaraas 2010:32). He further warned against entrusting the city's oldest history to the custody of a state museum, which would be an odd violation of historical continuity (Aaraas 2004:52). By 
emphasizing the value of the ships as "world famous national treasures rather than aspects of the history of Oslo" (Aaraas 2009:5), Aaraas is echoing the view of a number of debaters, for example Elisabeth Seip, who argued that Bjørvika is not "the appropriate museum area for the Viking ships. In Bjørvika, the story of the past is attached to mediaeval Oslo rather than to the Viking era" (Seip 2009:16). Aaraas' argument was also supported by Knut Olav Almås, a former commentator in Aftenposten: by the relocation of Oslo Museum to Bjørvika, the history of Oslo would be told in the "Mediaeval Park setting; the Viking ships, however, are hardly relevant as far as this history is concerned" (Åmås 2010:3). A sense of frustration also bothered Henrik Wigestrand, who criticized claims that the ships naturally belong to Oslo, "claims which prove that historical facts are subordinated to bureaucratic arguments" (Wigestrand 1997:2). He admitted, however, that this is what one might expect from a short-sighted city council that precipitated Oslo's 1,000th anniversary by many decades - in order to partake in the anniversary celebration (Wigestrand 1997:2). When asked by Dagsavisen about the advantage of moving the Viking ships to Bjørvika, Mikkelsen emphasized their access to Middelalderparken (the Medieval Park) and ancient Oslo (Larsen 2010:26). As for Aaraas' argument that the Reformation represents an artificial divide, a statement co-authored by Mikkelsen and current Rector of the University of Oslo, Ole Petter Ottersen, emphasizes the quite different collections of the Norsk Folkemuseum and the Museum of Cultural History, the former mainly representing archaeology and the latter focusing on ethnology (Ottersen and Mikkelsen 2009:5). Therefore, they claim, the scientific staff of either museum is only complementary to a small degree. This kind of statement is made rather rarely these days, the rewards of interdisciplinary cooperation being more commonly highlighted. June 15, 2012, however, the Museum of Cultural History issued a press release to the University Board, signed by Rane Willerled and Eilif Holte, recommending the building of a display and dissemination bridge between a Viking museum and the Norsk Folkemuseum. The bridge would facilitate access to the stave-church and medieval collection of the Norsk Folkemuseum. At the same time, joint plans for service facilities at the two museums should be examined (Museum of Cultural History 2012).

\section{Neglected and Outdated}

Many people have argued that the Viking Ship Museum at Bygdøy is outdated and unsuitable as a museum. One topic of discussion deals with the renovation of service facilities and the question whether such renovation requires relocation of the museum or not. Egil Mikkelsen argued that the buildings accommodating the ships have no air-conditioning, which makes them cold in the winter and hot in the summer. He further regretted that "there is no café in the Viking Ship Museum, the shop is too small, the ticket office is situated rather awkwardly, the parking areas are too small, and the traffic outside is rather chaotic" (Mikkelsen, 2001). Mikkelsen's complaints were shared by Gudleiv Forr, who also referred to the current lack of any service facilities at the museum (Forr 2002:2). Chair of the Museum of Cultural History Board, Trine Syvertsen, while regretting the lack of air-conditioning, also identified the security risk of "allowing crowds of spectators close to the ships" (Syvertsen 2006:12). She also called for better precautions against vandalism, fire, and other potential dangers. She further argued that the ships do not meet "the requirements of a modern museum, partly due to the lack of important facilities" (Syvertsen 2006:12). Hans Magnus Borge, Chair of Bygdøy Høyre (the Conservative Party), agreed with the condition report, claiming that the Viking Ship Museum does not fulfill 
"the requirements of a modern museum." He called it a "one time museum: if you have seen it, you have seen it" (Borge 2010:5). Jens A. Riisnæs described a recent visit to the Viking Ship Museum as a shocking, saddening, and embarrassing experience. According to Riisnæs, the ships are quite "fantastic; however, the museum provides little information, little interactivity, little history, dim lighting, and confusing exhibitions" (Riisnæs 2011:14). He even argued that tourists who look forward to watching something spectacular end up as visitors in a museum belonging to the Soviet era (Riisnæs 2011:14). Riisnæs' argument implies that the spectacular requires something beyond the ships-because the ships are already stored in the museum. He called for an experience arena and a 3D movie about the Viking age (Riisnæs 2011:14). Mikkelsen asked an Aftenposten journalist the following rhetorical question: "why does the National Gallery attract so many visitors?" Mikkelsen answered his own question: "because those who visit the café only are also counted" (Christiansen 2009:8). The true story that Mikkelsen did not tell, however, is the fact that the Viking Ship Museum, the café not included, draws more visitors than the National Gallery, which suggests that Mikkelsen's café argument does not quite explain why people visit museums. Arne Emil Christensen, while admitting to shortcomings of airconditioning and security, argued that improvements can be made on the spot at far lower expenses than a new building and the moving process would incur-and at no risk caused by moving (Christensen 2006:12). He added that despite a period of 15 years available for renovation planning, no initiative to this effect had been taken. In a message to the museum management, he summed this up as follows: "apparently, sins of omission are conveniently used as a pro-relocation argument" (Christensen 2006:12). An article co-authored by Knut Paasche at Norwegian Institute for Cultural Heritage Research contends that the "Viking ship collection has frequently been subject to unfair treatment" by the university as well as by the government (Christensen and Paasche 2012:4). According to Bjarne Rogan, professor of cultural history at the University of Oslo, the museum management had "given a new café a higher priority than museum subjects, including exhibitions." He believed that this was due to the fact that "most museum arguments support Bygdøy" (Rogan 2010a:5). Former medieval archaeologist, Inger Helene Vibe-Müller, characterized Mikkelsen's arguments as rather oversimplified and unbalanced because they contained neither remonstrance nor a necessary discussion. She also called for a critical media approach (Vibe-Müller 2006:12).

Maintenance neglect and old-fashioned methods of dissemination are two main arguments in the debate about the Viking Ship Museum. While the maintenance lag is an indisputable fact, opinions differ regarding the negative connotations of archaism. Although the ships and other artifacts may be viewed as archaic per se, many debaters call for the re-actualization of artifacts by means of modern methods of museum education and advanced technology. This might be the reason why Gudleiv Forr warned us against the conservation proposed by the Director for Cultural Heritage, as conservation would gradually convert "the Viking Ship Museum into a museum of a museum" (Forr 2009:58).

\section{The Replica as an Exhibition Strategy}

We can easily understand the wish of many people to move the Viking ships to a new museum of cultural history in Bjørvika, while we can also easily understand the arguments of those who want to keep them where they are-at Bygdøy. The idea of a dual solution has also been 
suggested, which will provide security for the ships - whether in Arnstein Arneberg's house or in a new building next to it-while also benefiting from the accessibility and attractiveness of Bjørvika. Anders Frøholm argued that Sørenga would inevitably trap the ships behind a wall of houses, which will bereave visitors of the opportunity of watching them in their natural environment. He therefore suggested the idea of making true replicas of the ships and displaying them on the sea part of the year (Frøholm 1997:29). Peter N. Waage also supported the idea of replicas, drawing a parallel to Michelangelo's David in Florence, where the replica is displayed in front of the city hall, while the original is accommodated by the museum (Waage 2007:2). What makes something authentic, Waage rhetorically asked: "is it form? Material? - or does authenticity rather deal with the relationship between the objects and their surroundings?" (Waage 2007:2). Waage added that the replicas-notably floating ship replicas-might be imbued with an authenticity of their own; at the same time, the replicas would protect the original ships against rough weather, vandalism, and considerations of prestige (Waage 2007:2).

Cultural journalist in Aftenposten, Lotte Sandberg, commented on the practical and philosophical implications of this kind of scenario by emphasizing "the pedagogical value of ship replicas as well as their substantial contribution to our knowledge" (Sandberg 2010:10). Quoting recent research, she identified the material fetishism of the original, although new theories of cultural heritage tend to emphasize the symbolic content rather than the "question of authenticity" (Sandberg 2010:10). By storing fragile originals at Bygdøy and displaying good replicas in Bjørvika, we would allow people to "touch the ships, and even climb aboard" (Sandberg 2010:10). Jon Winge advocated the idea of replicas in Bjørvika: "They are nearly as good as the originals, and much cheaper-and safer" (Winge 2010:26). He further commented on the replica of Gol stavkirke (a stave-church), arguing that "the replica status does not detract from the visitor's experience" (Winge 2010:26). It is difficult to identify arguments against the replica; which might be due to the debaters' support of conservation at Bygdøy—or moving to Bjørvika - while dual solutions are hardly considered.

\section{Opposition to the Plans}

Chief curator at the Norsk Folkemuseum, Terje Planke, argued that Mikkelsen and the Museum of Cultural History had systematically focused on the movability of the ships, without duly recognizing the "Viking Ship Museum as an institution with its own history of culture" (Planke 2009:4). He described their "strategy" as an attempt to "downgrade their own institution, including dissemination and storing conditions" (Planke 2009:4). A more optimistic view was expressed by long-standing relocation advocate and Mikkelsen supporter, Gudleiv Forr. Prior to Mikkelsen's retirement — at the announcing time of the director vacancy — he argued that the new director "will require considerable strategic skills," because "from the very first day, he will be involved in a fight for a new house" (Forr 2010b:2). Forr's argument seems to be based on the premise of the director sharing his own view in favor of Bjørvika. However, shortly after Mikkelsen resigned office as Director for the Museum of Cultural History, the fields of museum research launched another campaign against relocation (Østrem 2011:11). In an early statement, then Director, Rane Willerslev, proclaimed that his own position was against moving the ships (Gundersen and Gossner 2012:29). When the report was published, he rejoiced at the prospect of retaining the ships at Bygdøy (Røed 2012:45). Kristin Halvorsen, who described the 
"recommendations of the report as a model of clarity" (Christiansen 2012:12), considered the debate about relocation of the Viking ships to have "come to a close" (Semmingsen 2012:24). Public opinion has also been opposed to moving the ships; only 11 per cent of 803 Oslo citizens interviewed in 2010 argued in favor of Bjørvika, while 64 per cent argued in favor of Bygdøy (A. Christiansen 2010). A questionnaire conducted 15 years before rendered equal figures, 64 per cent of 604 considering relocation to be a bad idea (Nielsen 1997).

\section{Summing Up}

In general terms, one may argue that the working of a museum is mainly made up of "representation, interpretation, and dissemination" (Austbø 2012:30-31). In the context of the Viking ships, however, this argument is based on the conception of the material durability of the objects. In this case, the (fragile) materiality has to be included. As for the question of transportation risk, different views crystallize about risk proportions. Some people argue that the risk is too great to permit moving (at least not further than warranted by the state of the ships), whereas others consider the risk to be so small that the ships can, and should, be moved to Bjørvika. Many opponents to relocation also argue that risk is unjustifiable because the ships are world heritage objects that one is obliged to preserve for future generations. The Bjørvika champions, however, argue that there is only a minor risk of reparable transportation damage; therefore, they want the ships to be integrated in the urban development project in Bjørvika.

Irrespective of the ships' material durability, there are various reasons for moving to Bjørvika. One argument is related to the development of an international tourist arena in the vicinity of the cruise ship harbor; relocation champions also argue that Bygdøy is rather too remote, and that going there means travelling on roads heavily trafficked by coaches. Some people argue that the Oslo Central Station surroundings would be a more appropriate area of tourist reception than provided by the road to the present museum, whereas others have focused on the experience of watching Oslo from the sea, on a ferry from Medieval Oslo to Bygdøy. The Bygdøy alternative, while ensuring the preservation of the present museum, would also solve traffic problems. In prolongation of this argument, some people emphasize the maritime environment already existing at Bygdøy as a reason why the Viking ships should remain where they are today. The museums at Bygdøy encompass all Norwegian seafaring history-the Norwegian Maritime Museum, the Viking Ship Museum, the Fram Museum, and the Kon-Tiki Museum.

Another element of controversy is the question of whether the ships are to be inscribed in a burial or sea narrative. Those who argue against moving the ships regard ship and building as an inseparable entity - as Gesamtkunstwerk - that tells the story of Norse burial customs, whereas Bjørvika supporters emphasize proximity to water as essential for the display of the ships in their natural environment. Their vision is to move the ships to the reconstructed waterfront in Bjørvika (despite the wish of some people to move the ships back to Vestfold, where they were found and excavated). Others argue, however, that the Viking ships do not naturally belong in Bjørvika because they do not represent the history of Oslo. Another argument set forth is that the Museum of Cultural History in Bjørvika would be an illogical museum construction, because it would primarily represent the pre-Reformation era. Therefore, the recommended solution is to initiate a cooperation project with the Norsk Folkemuseum, which mainly represents the post-Reformation 
era. By so doing, one would be able to tell a continuous story from the Viking age up to the present time.

The service facilities at Bygdøy - and the question of whether the museum is outdated or notare also matters of controversy. The museum has no air-conditioning, and visitors moving close to the ships represent a security risk. Moreover, the collection is not sufficiently guarded against fire and other potential dangers. The museum also suffers from maintenance lag, and the exhibition, which is said to be rather old-fashioned, does not quite fulfill visitors' expectations. While these deficiencies are used as relocation arguments by some people, others argue that most faults can be remedied in the present museum. A dual solution has also been suggested, which allows the ships to stay at Bygdøy, while true replicas are made and set afloat in Bjørvika. This kind of solution would be inexpensive and safe — and possibly a success — provided that one does not succumb to original fetishism and the disparagement of replicas.

Summing up, one may argue that the museum field has been the main engine of the debate, supplemented, however, by other voices of public debate. The debate has also caught the interest of journalists and lay debaters, who have taken an active part in recommending various alternative solutions. The debate as performance is metacultural; it is cultural representations of cultural representations - in this case, the exhibition at the Viking Ship Museum. It is at this meta-level of representation that debates primarily take place (Hafstein 2009:18). Despite disagreement about the nature of a museum institution -in the museum field and in society at large - the campaign for the proposal has mainly been conducted by a group of people, headed by Mikkelsen, who have supported the local policy of integrating the ships in the urban development project in Bjørvika.

\section{Concluding Discussion}

A common critique of the developments in heritage studies is that it tends to reduce heritage to discursive processes, and that scholars have become more interested in the people behind the artifacts than in the artifacts themselves (Olsen 2010:38-39). This is also evident in the many attempts to inscribe the Viking ships into new narratives. In the academic world, social constructivism and the linguistic turn have brought along a growing interest in how the world is represented, and attempting to deconstruct people's perceptions of heritage has become a top priority (Rogan 2010b:260). Therefore, some people have voiced a need to deal more adequately with "things," and more specifically, the interconnectedness of people and objects (Harrison 2012:113). In the case of the Viking ships, discursive work has not been able to annul the physical risk of relocating the fragile objects. The Viking ship debate illustrates that material heritage cannot be reduced to a discursive metacultural performance only; it rather engages in an interdependent relationship with the material objects.

The concept of "discourse coalition" (Hajer 1995:65) can be attached to a group of actors-for example debaters - who share an opinion of an issue, in this case, for or against relocation of the Viking ships. Although the debaters do not necessarily share general views or political ideologies, they partake in the metacultural debate because they share some basic ideas. This is a valid description of the re-localization debate. A successful discourse coalition has a potential to 
be institutionalized. As for the debate about the Viking ships, it is primarily a discourse coalition approaching institutionalization status, that is, the coalition that highlights the Bjørvika advantages of tourism development, accessibility, and the Bilbao-effect potential. However, the Bjørvika candidacy has been effectively thwarted by assessment reviews about the material vulnerability of the ships - as well as by reasoned arguments stating that the ships should remain where they are today — at Bygdøy.

Because of their status as international treasures, the Viking ships are torn between different interests. The faith in the ability of museums to reclaim city areas is inspired by a "just add culture and stir"-philosophy which has achieved a hegemonic status among many urban developers (Gibson and Stevenson 2007:1). One may argue that the rise of cultural heritage is an example of a "newfound valuation of cultural practices and objects in terms of their expediency for economic and political purposes" (Hafstein 2012:503). Yet, a distinction can be made between museums that serve public interest and have a responsibility for their "products," and those primarily concerned with profit (Kirshenblatt-Gimblett 1998:171). The Viking Ship museum serves as an important social institution that, however, cannot encompass everything and serve all purposes. In the matters of cultural economics, there are several values other than economic. For example, "existence value," which refers to the value of the mere existence of a cultural asset, while "bequest value" refers to the value that an asset may have for later generations (Kirshenblatt-Gimblett 2006:30). Adhering to these values, one would advise against relocation. On the other hand, "prestige value" is about the value of being proclaimed world heritage, and this value is often used to gain economic profit in terms of tourism (KirshenblattGimblett 2006:30). However, there would be little prestige in damaged treasures.

The arguments in favor of Bjørvika seem to emphasize an increasing number of visitors rather than the discussion of the suitability of Bjørvika as a stage for historical display and dissemination. Furthermore, those in favor of relocating the Viking ships have tried to construct a "spatial narrative" around Bjørvika that tries to "re-aestheticize" the area to fit the gaze of the tourists (Mordue 2010:174). Still, the Bjørvika neighborhood is quite similar to waterfront projects found elsewhere. Kirshenblatt-Gimblett (1998) argues for "the value of difference:" to compete for tourists, a location must become a "destination," and this destination must be distinguishable. "Sameness" is therefore a problem for the tourist industry that aspires to "hereness" (Kirshenblatt-Gimblett 1998:152-153). Hypothetically, one may wonder if relocating the Viking ships to Bjørvika would be enough to create this uniqueness, considering the fact that the ships would be located behind modern high-rise office blocks primarily housing finance institutions. Many scholars have criticized urban regeneration projects that disregard each city's local characteristics. Tourists search for the unique and local, rather than waterfronts that have the same "international" look, and tourists often prefer the old and historical to the new (Chang and Huang 2010:2096-2099). It has also been observed that when all cities pursue similar strategies, it may result in the very sameness that they are trying to avoid (Zukin 2010:231). There is a captious irony in this: the more Europe becomes Disneyfied, the less special it becomes (Harvey 2002:95).

Dagfinn Skre argued that the fate of the ships should no longer be "determined by other agendas, and that the ships have to develop an agenda of its own" (Skre 2006:11). He further claimed that their future has to be separated from the relocation issue in order to ensure provident 
conservation and dissemination of the ships and not focused only on immediate measures like those proposed by the University Board (Skre 2006:11). The empirical corpus seems to support this argument, as the debate obviously reflects a lack of long-term reasoning. Furthermore, there has been a lack of will and means for regular maintenance, and different relocation scenarios are entangled in local policy resolutions and national political aims. The debate demonstrates that many people tend to emphasize the various purposes the ships can serve, rather than the ideal future management of the ships and other objects. If more debaters had acknowledged that heritage is also about objects - fragile in this case - the ships might not have been drawn into the urban development project in Bjørvika. In the long run, the museum seems to require a more clearly defined agenda as a basis for future decision-making.

\section{References Cited}

Aaraas, Olav

2004 Kulturhistorisk museum på Bygdøy [Museum of Cultural History at Bygdøy]. Dagbladet, April 26: 52.

2009 Helhetlig sammenheng [Coherent connection]. Aftenposten, Descember 15: 5.

2010 Gi oss en helhet $\mathrm{i}$ historieformidlingen [Give us the full dissemination of history]. Aften, June 23: 32.

Åmås, Knut Olav

2010 Bygdøy, ikke Bjørvika! [Bygdøy, not Bjørvika!]. Aftenposten, Febryary 1: 3.

Andersen, Jørgen

2010 La vikingskipene stå i fred! [Leave the Viking ships alone!]. Dagsavisen, March 18: 4.

Andreassen, Thorleif

2010 "Flytter vikingskipene, flytter nok vi" [If the Viking ships moves, we will also move]. Aftenposten, February 4: 6-7.

Austbø, Anne Tove

2012 Sjøfolks medbrakte gjenstander: en problematisk museumskategori? [Sailors' collected treasures: a delicate matter for a museum?]. Tidsskrift for kulturforskning 11(1):25-29.

Bauge, Maja

2010 Sjøfarer eller landkrabbe? [Sefarer or landlubber?]. Aftenposten, November 19: 5. 
Borge, Hans Magnus

2010 Vi ønsker ikke et gigantmuseum [We do not want a gigantic museum]. Aftenposten, February 4: 5 .

Borgen, Gro

2009 Sats på fergetransport! [Go for ferry transport!]. Aften, November 4: 41.

Brynildsen, Kjell

2006 Siste krampetrekning [The last agony]. Aftenposten, December 23: 11.

Brække, Jonas

2007 Vil ha vikingskipene ved sitt rette element [We want the Viking ships to stay in their true element]. Dagsavisen, March 16: 34.

Chang, T. C., and Shirlena Huang

2010 Reclaiming the City: Waterfront Development in Singapore. Urban Studies 48(10):20852100.

Christensen, Arne Emil

2006 Flyttingen kan gå helt galt [Relocation may go completely wrong]. Aftenposten, December 13: 12.

Christensen, Arne Emil, and Knut Paasche

2012 Nå må Norge tørre å satse [Now Norway must dare to venture]. Aftenposten, May 8: 4-5.

Christiansen, Ann

2009 Slår tilbake mot Bygdøy [Fighting against Bygdøy]. Aftenposten, December 6: 8.

2012 Vikingskipene er i havn [The Viking ships are in port]. Aftenposten, May 4: 12.

Christiansen, Jan

1997 Hvis nå vikingskipene kan flyttes [If the Viking ships can be moved]. Aften, March 4: 32.

Dagsland, Sissel Hamre

2002 Strid om flytting av vikingskipene [Dispute about relocating the Viking ships]. Bergens Tidende, December 10: 40. 
Directorate for Cultural Heritage

2006 Varsel om oppstart av fredningssak, kulturminneloven $\S 22$ A JF. $\S 15$ [Notification of started protection process, Cultural Heritage Act]. http://www.riksantikvaren.no /?module=Articles;action=Article.publicShow; $\mathrm{ID}=4124$, accessed March 10, 2013. [Not accessible as of November 17, 2015]

Editorial

1995 Hvor skal Oslos museer plasseres? [Where are Oslo's museums to be located?]. Aftenposten, October 15:8.

2012 Museal politikk [Museal politics]. Dagbladet, May 13: 2.

Ellingsrud, Geir

2006 Vikingskipene skal flyttes til Bjørvika [The Viking ships shall be moved to Bjørvika]. Aftenposten, December 22: 12.

Florida, Richard

2002 The Rise of the Creative Class: And how it's transforming work, leisure, community and everyday life. New York: Basic Books.

Forr, Gudleiv

2000 Nordens Pompeii [Nordic Pompeii]. Dagbladet, December 16: 2.

2002 Vikingarven smuldrer [The Viking heritage is pulverizing]. Dagbladet, March 30: 2.

2009 Museum over et museum [Museum of a museum]. Dagbladet, July 24: 58.

2010a Historien til Bjørvika [Bjørvika’s history]. Dagbladet, February 3: 62.

2010b Ny byggmester [New master builder]. Dagbladet, December 14: 2.

Frøholm, Anders

1997 Skal vi flytte vikingskip? [Are we going to move Viking ships?]. Aften, February 25: 29.

Gibson, Lisanne, and Deborah Stevenson

2007 Urban Space and the Uses of Culture. International Journal of Cultural Policy 10(1):1-4. 
Grande, Toril

1997 Med sverd skal landet selges [With sword shall the country be sold] . Dagbladet, July 27: 10 .

Grønvold, Ulf

2010 Skipene er det viktigste [The ships are most important]. Aftenposten, Febryary 18: 3.

Gullbekk, Svein

2010 Bygdøy svekker minoritetene! [Bygdøy weakens minorities!]. Aftenposten, February 3: 5 .

Gundersen, Håkon, and Ellen Lande Gossner

2012 Kvikkas med tyngde [Agile and weighty]. Morgenbladet, April 20: 29.

Hafstein, Valdimar T.

2009 Collectivity by Culture Squared. In Arv: Nordic Yearbook of Folklore. A.B. Amundsen, ed. Pp. 11-23. Uppsala: Swedish Science Press.

2012 Cultural Heritage. In A Companion to Folklore. R. Bendix and G. Hasan-Rokem, eds. Pp. 500-519. Malden, MA: Wiley-Blackwell.

Hagen, Anders

2012 Flytting stopper museum [Relocation stops museum]. Dagens Næringsliv, May 4: 84. Hajer, Maarten A.

1995 The Politics of Environmental Discourse: Ecological Modernization and the Policy Process. Oxford: Clarendon Press.

Harrison, Rodney

2012 Heritage. Critical Approaches. London: Routledge.

Harvey, David

2002 The Art of Rent: Globalization, Monopoly and the Commodification of Culture. Socialist Register 38(1):93-110.

Haugen, Svein Erik

1999 Vikingskipene [The Viking ships]. Dagbladet, October 6: 43. 
Herbjørnsrud, Dag

1997 Overraskende forslag i Oslo bystyre: Flytt vikingskipene til Sørenga [Surprising suggestion in Oslo City Parliament: Move the Viking ships to Sørenga]. Aften, February 11: 28 .

International Expert Committee

2012 Risk Assessment Moving of Historical Viking Ships From Bygdøy. Report for Norwegian Ministry of Education and Research, vol. 2014. http://www.regjeringen.no/upload/KD/ Vedlegg/Forskning/rapporter/Report_RiskAssessmentVikingShips.pdf, accessed February $2,2014$.

Kirshenblatt-Gimblett, Barbara

1998 Destination Culture. Tourism, Museums, and Heritage. Berkeley: University of California Press.

2006 World Heritage and Cultural Economics. In Museum Frictions: Public Cultures/Global Transformations. C. Rassool, B. Kirshenblatt-Gimblett, G. Buntinx, and I. Karp, eds. Pp. 161-206. Durham, N.C.: Duke University Press.

Klem, Cecilie

1995a Flytting gir turist-flukt [Relocation leads to tourist flight]. Aften, October 25: 17.

1995b Galskap å flytte! [Madness to move!]. Aften, October 12: 15.

1995c Vikingskipshuset på verneliste [The Viking Ship Museum on the conservation list]. Aften, November 1: 18.

1996 Historisk Museum flyttes til Tøyen [Historical Museum moves to Tøyen]. Aften, April 23: 3 .

Kolsrud, Jan Birger

2001 Ikke flytt vikingskipene fra Bygdøy [Do not move the Viking ships from Bygdøy]. Aftenposten, January 30: 18.

Kraft, Nina

2012 Eventyreren som vil omskape Kulturhistorisk museum [The adventurer that wants to transform the Museum of Cultural History]. Ukeavisen Ledelse, March 16: 30-31. 
Kristensen, Eivind

2006 Stø kurs mot Bjørvika [Steady course towards Bjørvika]. Dagbladet, December 20: 46.

Kvistad, Yngve

2010 Skipbrudd i Bjørvika [Shipwrecked in Bjørvika]. VG, February 4: 2.

Langfeldt, Jan G.

2010 Trist rapport fra Oslo [Sad report from Oslo]. Aftenposten, November 30: 3.

Larsen, Mona

2010 Holder fast på Bjørvika [Still going for Bjørvika]. Dagsavisen, February 2: 26.

Lillebø, Sandra

2012 Denne beslutningen er forhastet [This descision is too rash]. Klassekampen, May 4: 2021.

Lilleås, Heidi Schei

2012 Her er beviset [Here is the evidence]. http://www.nettavisen.no/nyheter/3389424.html, accessed June 14, 2012.

Løken, Kjersti

1995 Overblikket: Vikingskipet [The overview: The Viking ship]. Aften, October 13: 2.

Mikkelsen, Egil

2001 Bør vikingskipene flyttes? [Ought the Viking ships to be moved?]. Aftenposten, February 24: 8 .

Mordue, Tom

2010 Time Machines and Space Craft. In Culture, Heritage and Representation: Perspectives on Visuality and the Past. E. Waterton and S. Watson, eds. Pp. 173-194. Farnham: Ashgate.

Nissen-Lie, Henrich

2009 Sjøveien til Bygdøy [The sea route to Bygdøy]. Aften, November 11: 19. 
Norenberg, John Tore

2009 Dødfødt med nytt museum på Bygdøy [A new museum at Bygdøy is stillborn]. Aften, November 10: 27.

Museum of Cultural History

2012 Pressemelding fra Kulturhistorisk museum [Press release from Musuem of Cultural History]. Ny lokalisering for $\mathrm{KHM}$ [New localization of $\mathrm{MCH}$ ]. Oslo: Universitetet i Oslo.

Olsen, Bjørnar

2010 In Defense of Things: Archaeology and the Ontology of Objects. Lanham, Md.: AltaMira Press.

Østrem, Veslemøy Hedvig

2011 Museumsomkamp [Museum play-off]. Aftenposten, November 30: 11.

Ottersen, Ole Petter, and Egil Mikkelsen

2009 Fremtidens museum [Museum of the future]. Aftenposten, August 21: 5.

Peck, Jamie

2005 Struggling with the Creative Class. International Journal of Urban and Regional Research 29(4):740-770.

Planke, Terje

2009 Vikingskipenes makt [The power of the Viking ships]. Aftenposten, December 2: 4.

Rekdal, Per

2009 Flytt dem! Vær så snill [Move them! Please]. Morgenbladet, August 28: 17.

Riisnæs, Jens A.

2011 Museet trenger ny innpakning [The museum needs a new wrapping]. Aften, August 3: 14.

Rindal, Magnus

2003 Middelalder-Oslo i "bakgården" [Mediaeval Age Oslo in the "backyard”]. Aften, May 21: 44. 
2006 Oslo: den historielause hovudstaden? [Oslo: the capital without a sense of history?]. Aftenposten, December 22: 12.

Rogan, Bjarne

2010a Nitrist kulturmuseum [A miserable museum of culture]. Aftenposten, February 3: 5.

2010b Tingenes transformasjoner i museet. Mellom kontekst, språk, estetikk og politikk [The transformation of things in the museum: Between context, language, and politics]. In Samling og museum [Museum and collection]. B. Rogan and A.B. Amundsen, eds. Pp. 255-276. Oslo: Novus forlag.

Røed, Lars-Ludvig

2012 Vikingen [The Viking]. Aftenposten, May12: 44-46.

Røsholm, Knut

2002 Vikingskipene må få hvile [The Viking ships must be allowed to rest]. Aften, November 13: 44.

Sandberg, Lotte

2010 Ingen grunn til å kimse av kopier [No reason to scorn copies]. Aftenposten, March 28: 10.

Sandvig, Helge

1995 Skån oss for skandalen! [Save us from the scandal!]. Aftenposten, November 1: 10.

Seip, Elisabeth

2009 Bevar Vikingskiphuset! [Protect the Viking Ship Museum!]. Aften, July 2: 16.

Semb, Ellen

2010 Kulturhistorie i kontekst [Cultural history in context]. Aften, July 22: 16.

Semmingsen, Inga

2012 Vikingskipene må bli [The Viking ships have to stay]. Dagsavisen, May 4: 24.

Skre, Dagfinn

2006 Vikingskipenes fremtid [The future of the Viking ships]. Aftenposten, November 27: 11. 
Skrede, Joar

2014 "The Value of Culture": Discourse Approaches to Culture, Capital and Urban Change. Ph.D. dissertation, Department of Culture and Global Studies, Aalborg University.

Slettholm, Andreas

2012 Bjørvika kan bli museumsfritt [Bjørvika may become free of museums]. Aftenposten, May 15: 12-13.

Syvertsen, Trine

2006 Skipenes fremtid er viktigst [The ships' future is most important]. Aftenposten, December 13: 12 .

Toft, Martin

2006 Må flytta frå vikingskipa [Has to move from the Viking ships]. http://www.uniforum.uio.no/nyheter/2006/11/maa-flytta-fraa-vikingskipa.html, accessed June 14, 2012.

2010 Erling Lae vil ha vikingskipa på Bygdøy [Erling Lae wants to keep the Viking ships at Bygdøy]. http://www.uniforum.uio.no/nyheter/2010/06/erling-lae-vil-ha-vikingskipa-pabygdoy.html, accessed August 28, 2014

Tove Lisbet, Øyvind Riise Jenssen, Bjørn-Ole Gleditsch, Per Arne Olsen, and Nils Henning Hontvedt.

2006 Vikingskipene tilbake til Vestfold [The Viking ships back to Vestfold]. Aftenposten, December 28: 11.

Vibe-Müller, Inger Helene

2006 Bevaring er viktigst [Protection is most important]. Aftenposten, November 29: 12.

Waage, Peter Normann

2007 Lag kopier av vikingskipene [Make replicas of the Viking ships]. Aftenposten, February 8: 2.

Wigestrand, Henrik

1997 Oslos kulturvandaler fornekter seg ikke [Oslo's cultural vandals are incorrigible]. Aften, February 17: 2 . 
Winge, Jon

2010 Bygdøy er vårt nasjonale Greenwich [Bygdøy is our national Greenwich]. Aften, September 14: 26.

Zukin, Sharon

2010 Naked City: The Death and Life of Authentic Urban Places. Oxford: Oxford University Press.

Joar Skrede is a sociologist and researcher at the Norwegian Institute for Cultural Heritage Research, Department of Policy, Management and Society.

http://dx.doi.org/10.14434/mar.v10i1.19207 